\title{
PHLEBOTOMINES (DIPTERA, PSYCHODIDAE) FROM BURKINA FASO. A NOTE ON THE SANDFLY SPECIES COLLECTED IN DOMESTIC RESTING SITES
}

\author{
M. MAROLI*, A. M. FAUSTO*, G. SABATINELLI**, G. MAJORI*
}

\begin{abstract}
SUMMARY. A total of 1,394 sandflies were collected in the domestic resting sites of Ouagadougou areas and in two villages of the East region of Burkina Faso using pyrethrum spray catch, oiled papers and miniature CDC light traps during the rainy season in 1984 and 1985 . Thirteen species were identified, one belonging to the genus Phlebotomus and the others to the genus Sergentomyia. S. antennala (34.94\%), S. bedfordi (16.64\%), S. clydei (14.42\%), S. schwetzi (13.20\%), P. duboscqi $(8.46 \%), S$. adleri $(7.03 \%)$ and $S$. africana $(2.87 \%)$ were in order of percentage the more abundant species. The abdominal stages of the sandfly species caught in the human habitations are described. $P$. duboscqi, the suspected vector of cutaneous leishmaniasis in the area, seems to have a preferential domestic biotope.
\end{abstract}

\section{Les phlébotomes (Diptera, Psychodidae) du Burkina Faco. Une note sur les espèces capturées dans les habitations humaines}

RÉSUMÉ. Une enquête entomologique a été effectuée durant la saison des pluies en 1984 et 1985 , dans les environs de Ouagadougou et dans deux villages de la région orientale du Burkina-Faso (sites domestiques de repos). A l'aide de pulvérisations de pyrètre, des pièges adhésifs et lumineux modèle CDC, 1394 phlébotomes ont été récoltés. Treize espèces ont été identifiées, l'une d'entre elles appartenant au genre Phlebotomus et les autres, au genre Sergentomyia. Les espèces identifiées sont rapportées par ordre de densité décroissante. Ce sont $S$. antennata $(34,94 \%)$, S. bedfordi $(16,64 \%)$, S. clydei $(14,42 \%)$, S. schwetzi $(1320 \%)$, P. duboscqi $(8,46 \%)$, S. adleri $(7,03 \%)$, S. africana $(2,87 \%)$, S. buxtoni $(0,79 \%)$, S. magna $(0,65 \%)$, S. affinis vorax $(0,57 \%)$, S. dubia $(0,07 \%)$ et $S$. inermis $(0,07 \%)$. Les captures sont analysées et quelques observations sont faites sur les différents états abdominaux des espèces capturées dans les habitations. Le $P$. duboscqi, vecteur suspecté de transmettre la leishmaniose cutanée dans la zone étudiée, paraît avoir essentiellement un biotope domestique.

\section{Introduction}

The initial detection of cutaneous leishmaniasis (CL) in Burkina Faso (formerly Upper Volta) was reported by Lariviere et al. (1961). Later Oddou (1962) described

- Istituto Superiore di Sanità, Parasitology Department, Viale Regina Elena, 299, 00161 Rome, Italy.

** Centre de lutte contre le paludisme, Département pour la Coopération au Développement, Italie -Burkina Faso, B.P. 2208, Ouagadougou, Burkina Faso.

Accepté le 3 juillet I 986 . 
13 CL cases (of which one from Ouagadougou) during a period of 23 months of observations. One case of generalized CL was described by Menard et al. (1970) and André et al. (1978) reported in an European child a case resembling diffuse cutaneous leishmaniasis associated with visceral infection.

Very few studies are carried out on sandflies in the region. Abonnenc and Pastre (1971) reported the results of 17 years of collections (1953-1969). A total of 1,753 specimens were collected from more than 100 localities, being the stations more visited in the areas of Bobo Diulasso, Tougan and Tenkodogo. Twenty-three sandfly species were identified : Sergentomyia schwetzi, Phlebotomus duboscqi, S. adleri, S. squamipleuris, S. africana and S. clydei were the species with the higher density ; observations on the biology and ecology of the species were also noted, particulary man biters. $P$. duboscqi was highly suspected of transmitting CL in the region.

Since 1983 within the framework of Italian Government cooperative program with Developing Countries, a project of malaria and vector control has been established in the Ouagadougou areas. During studies on malaria vectors in Ouagadougou town and nearby villages many specimens of phlebotomine sandflies were collected in the domestic resting sites, by means of pyrethrum spray cacth (PSC).

The present note reports the results of two years collections carried out in Ouagadougou areas during the rainy seasons of 1984 and 1985.

The results of a single catch made in the villages of Bougi and Baskoure (East part of the country) are also reported.

\section{Materials and methods}

\section{Place}

The Ouagadougou area is located in a typical Sudan savanna region with rainy season from June to September. A number of basins in the urban and neighbouring rural areas supply water for agricultural and domestic purposes. The Ouagadougou town is divided into 30 sectors. Sixty percent of the urban area has no regular urban infrastructures (roads, electicity, water supply etc.).

The rural area is characterized by the presence of quite a few villages with widespread houses surrounded by small stripes of cultivated land. The houses are essentially of two types. One is the traditional circular "Mossi hut" made of unbaked bricks of clay soil with conical straw roof. The other is a rectangular 2-rooms house made of the same material and covered with ondulated metal sheet. Usually 2-4 people sleep in the same room. Animal shelters are present near the houses. The most common animals bred are chickens, sheep, pigs and cattle. The localities of the collecting stations and the type of houses used for PSC are given in Table I.

TIME

Sanfly collections were made in the morning from 8.00 to 10.00 during the rainy seasons of 1984 and 1985 from June to end of August. 
TABLE I. - Locations of the collecting stations and type of houses in which PSC were carried out

\begin{tabular}{|c|c|c|c|}
\hline $\begin{array}{l}\text { Localities of } \\
\text { the collecting } \\
\text { stations }\end{array}$ & Province & $\begin{array}{l}\text { Distances from } \\
\text { Ouagadougou }\end{array}$ & $\begin{array}{c}\text { Type } \\
\text { of houses }\end{array}$ \\
\hline Town of Ouagadougou & Kadiogo & & (b) \\
\hline Villages of Zagtouli & Kadiogo & $12 \mathrm{Km}$ South-West & (a), (b) \\
\hline "Pabré & Oubritenga & $20 \mathrm{Km}$ North & (a), (b) \\
\hline Balkoui & Kadiogo & $12 \mathrm{Km}$ South & (a) \\
\hline Koubrì & Bazega & $27 \mathrm{Km}$ South & (a), (b) \\
\hline Baskouré & Kourittenga & $159 \mathrm{Km}$ East & (a) \\
\hline Bougi & Gourma & $232 \mathrm{Km}$ East & (a) \\
\hline
\end{tabular}

(a) $=$ Mossi hut; (b) = rectangular 2-rooms

\section{METHODS OF COLLECTION AND IDENTIFICATION}

Sandflies were caught inside the bed-rooms by using PSC. Commercial aerosol of $0.2 \%$ of pyrethrum extract, in a pressurized spray can, was applied for 15 seconds ; after 10 minutes sandflies were collected with entomological forceps on the white sheet previously spread out on the floor surface of the house. CDC miniature light traps and castor oil papers $(20 \times 20 \mathrm{~cm})$ were also used in the village of Zagtouli in 1985 ; animal shelters ( $10 \mathrm{~m}$ from the houses), crevices of a baobab tree $(200 \mathrm{~m}$ from the houses) and two termite hills, located at 2 and $5 \mathrm{~km}$ from the village, were inspected for the presence of sandflies.

The collected specimens were cleared in chlor-lacto-phenol at $40^{\circ} \mathrm{C}$ for five days and mounted in phenol-balsam. All specimens were identified according to Abonnenc (1972) and to the recent classification of Lewis (1977).

\section{Results and discussion}

A total of 1,394 phlebotomines, of which $27.18 \%$ were male specimens, were collected during the two years of collection. Thirteen species were identified, one belonging to the genus Phlebotomus and 12 to the genus Sergentomyia. Abonnenc and Pastre (1971) found 23 species in the whole country. The lower number of species identified could be referred to the limited area studied, to the particular resting sites inspected and to the short period (June-August) of collection.

Table II shows the species identified in the two periods of catches, the frequencies and male percentages for each species. The male percentages of the species more abundant were between $48.75 \%$ of $S$. clydei and $14.78 \%$ of $S$. antennata. The species with higher percentages are the same reported by Abonnenc and Pastre (1971) except for S. squamipleuris ; a density of $9.60 \%$ was found for this species by the authors cited, while no specimen was identified in our collections. This could be due to the behaviour of the species which generally lives in the vegetation. Regard- 
TABLE II. - Sandfly species collected in Ouagadougou areas, and in Bougi and Baskouré villages during June-August 1984 and 1985

\begin{tabular}{lccc}
\hline \multicolumn{1}{c}{ Specres } & $\begin{array}{c}\text { Total of } \\
\text { collected } \\
\text { specimens }\end{array}$ & $\begin{array}{c}\text { Species } \\
\%\end{array}$ & $\begin{array}{c}\text { Males } \\
\%\end{array}$ \\
\hline Phlebotomus (Phlebotomus) duboscqi & 118 & 8.46 & 20.33 \\
Sergentomyia (Sergentomyia) antennata & 487 & 34.94 & 14.78 \\
Sergentomyia (Sergentomyia) bedfordi & 232 & 16.64 & 28.44 \\
Sergentomyia (Sergentomyia) buxtoni & 11 & 0.79 & 9.09 \\
Sergentomyia (Sergentomyia) dubia & 1 & 0.07 & 0.00 \\
Sergentomyia (Sergentomyia) schwetzi & 184 & 13.20 & 34.78 \\
Sergentomyia (Grassomyia) ghesquierei & 4 & 0.29 & 0.00 \\
Sergentomyia (Grassomyia) inermis & 1 & 0.07 & 0.00 \\
Sergentomyia (Sintonius) adleri & 98 & 7.03 & 41.83 \\
Sergentomyia (Sintonius) affinis vorax & 8 & 0.57 & 37.50 \\
Sergentomyia (Sintonius) clydei & 201 & 14.42 & 48.75 \\
Sergentomyia (Parrotomyia) africana & 40 & 2.87 & 22.50 \\
Sergentomyia (Parrotomyia) magna & 9 & 0.65 & 11.10 \\
\hline Total & & & 27.18 \\
\hline
\end{tabular}

ing the collections with CDC light traps and oiled papers, it can be noted that with these methods any specimen of $P$. duboscqi and $S$. clyde $i$ was collected outside, while in the domestic resting sites of the village 59 and 76 specimens respectively were caught with PSC in the same period.

Our data show also that $P$. duboscqi is more present $(20.00 \%)$ in urban area of Ouagadougou town than in the rural areas of the villages $(7.57 \%)$.

Table III reports the female percentages, at different abdominal stages for each species caught in the domestic resting sites of Zagtouli village in 1985 . Considering the species with highest percentage, S. antennata showed the higher female percentage $(92.69 \%$ ) followed by $P$. duboscqi $(84.75 \%)$; for S. clydei, S. schwetzi and S. adleri the sex ratio was about $1: 1 . P . d u b o s c q i$ was the species with the higher percentage of fed females $(82.00 \%)$ followed by S. adleri $(64.00 \%)$ and $S$. clydei $(58.13 \%)$. The percentages of unfed females were higher in $S$. schwetzi $(78.12 \%$ ) and $S$. antennata $(64.47 \%)$. In the last column of Table III is reported for each species the number of blood smears tested for the host preference. The smears were not well preserved and very few gave a positive reaction. One specimen of $P$. duboscqi and $S$. adleri were positive for mammal. Positive reaction for $S$. clydei was as follows : mammals (4 smears) ; bovid (1 smear) ; rodents (1 smear), suid (1 smear) and rodent + suid ( 1 smear).

From the above results some epidemiological considerations could be made. $P$. duboscqi, the only suspected vector of $\mathrm{CL}$ in the region, was present in human 
TABLE III. - Sandfly species caught in the domestic resting sites of Zagtouli village in 1985 and female percentages at different abdominal stages

\begin{tabular}{lcccccc}
\hline SPEcIES & $\begin{array}{c}\text { Total of } \\
\text { specimens } \\
\text { collected }\end{array}$ & $\begin{array}{c}\text { Females } \\
\%\end{array}$ & & \multicolumn{2}{c}{$\begin{array}{c}\text { FEMALES AT DIFFERENT } \\
\text { ABDOMINAL STAGES (\%) }\end{array}$} & $\begin{array}{c}\text { No of } \\
\text { blood smears } \\
\text { tested }\end{array}$ \\
\cline { 3 - 6 } & & & Unfed & Fed & Gravid n & \\
\hline P. duboscqi & 59 & 84.75 & 10.00 & 82.00 & 8.00 & 8 \\
S. antennata & 82 & 92.69 & 64.47 & 25.00 & 10.52 & 9 \\
S. bedfordi & 17 & 70.59 & 83.33 & 8.33 & 8.33 & - \\
S. dubia & 1 & 1.0 & 1.0 & - & - & - \\
S. schwetzi & 60 & 53.34 & 78.12 & 18.75 & 3.12 & - \\
S. ghesquierei & 2 & 2.0 & 2.0 & - & - & - \\
S. adleri & 46 & 54.35 & 20.00 & 64.00 & 16.00 & 6 \\
S. clydei & 76 & 56.58 & 32.55 & 58.13 & 9.30 & 9 \\
S. africana & 7 & 85.72 & 100.00 & - & - & - \\
S. magna & 2 & 2.0 & 2.0 & - & - & - \\
\hline \multicolumn{1}{c}{ Total } & 352 & & & & & 32 \\
\hline
\end{tabular}

dwellings but it was apparently absent in outside shelters. Moreover, high percentages of $P$. duboscqi freshly engorged females were collected during the first hours of the morning in the human habitations, with 2-4 person sleeping during the night. On the other hand, its anthropophily had been determined in several countries of west Africa (Roubaud, 1913 ; Parrot and Gougis, 1943 ; Rageau, 1951 ; Lariviere et al., 1961). All the above suggests that $P$. duboscqi, in the area under study, might have a preferential domestic biotope despite the fact that in Senegal this species was localized in the biotope of rodent burrows (Desjeux and Dedet, 1982). If this hypothesis is true, $P$. $d u b o s c q i$ may not have any interaction with the CL reservoirs that in West Africa have been shown to be some wild rodent species (Dedet et al., 1981).

From an epidemiological point of view, the different behaviour of $P$. duboscqi could represent a weakness in the CL transmission in the area, supporting one of the hypotheses reported by Zahar (1981) to explain the apparent absence of CL cases from the region after the initial report of a series of cases (Oddou, 1962).

Nevertheless, specific surveys of sandfly species have to be carried out as well as the active CL case detection in urban and rural areas. This is needed for determining the degree of prevalence of CL.

Acknowledgements. We are grateful to Prof. M. Coluzzi, Institute of Parasitology, University of Rome "La Sapienza " and Dr. G. Bertolaso, Department for Cooperation to Development, Ministry of Foreign Affairs, Italy for the encouragement and opportunity of carrying out this investigation.

We are greatly indebted to Dr. Richard Lane for the opportunity of examining the sanfly type specimens from British Museum (N. H.). We would like to thank Dr. E. Abonnenc, Dr. N. Leger and Dr. D. J. Lewis for critical reading of the manuscript. 
The authors also wish to thank Dr. R. Killick-Kendrik for the blood meals analysis. The help of Dr. Bibané Lallé, Director of Epidemiological Service and Vaccination, Ministry of Health, Burkina Faso, and the local staff in Ouagadougou are much appreciated.

\section{REFERENCES}

Abonnenc E. : Les phlébotomes de la région éthiopienne (Diptera, Psychodidae). Mémoires ORSTOM, 1972, $55,289$.

Abonnenc E., Pastre J.: Phébotomes de la Haute-Volta (Diptera, Psychodidae). Notes biologiques. Cah. ORSTOM Ent. Med., I971, 9, 387-416.

André L. G., Sirol J., Le Vourch C., Labegorre J., Cochevelou D. : Sudanese Kala-azar in West Africa. Med. Trop., I $978,38,435-442$.

Dedet J. P., Hubert B., Desjeux P., Derouin F. : Écologie d'un foyer de leishmaniose cutanée dans la Région de Thiès (Sénégal, Afrique de l'Ouest). 5. Infestation spontanée et rôle de réservoir de diverses espèces de rougeurs sauvages. Bull. Soc. Path. Exot. I981, 74, 7I-77.

Desjeux P., Deder J. P. : Écologie d'un foyer de leishmaniose cutanée dans la Région de Thiès (Sénégal, Afrique de l'Ouest). 7. Synthèse épidemiologique après cinq années d'observation et hypothèse de fonctionnement. Bull. Soc. Path. Exot., 1982, 75, 620-630.

Larivieke M., Abonnenc E., Kramer R. : Chronique de la leishmaniose cutanée en Afrique Occidentale. Problème du vecteur. Bull. Soc. Path. Exot., 196r, 54, I03I-I046.

LEwis D. J. : Proposal for a stable classification of the Phlebotomine sandflies (Diptera: Psychodidae). System. Entomol., 1977, 2, 319-332.

MenaRd M., Gidel R., Ghipponi P.: A propos d'un cas de Leishmaniose cutanée généralisée chez un nourrisson en Haute-Volta. Ann. Soc. Belges Méd. Trop., 1970, 50, 28I-292.

Oddou A. : Sur treize cas de leishmaniose cutanée en Haute-Volta. Bull. Soc. Med. Afrique Noire, I $962,7,284-287$.

Parrot L., Gougrs R. : Sur l'agent probable de transmission du bouton d'Orient dans la colonie du Niger. Arch. Inst. Pasteur Alger, 1943, 2I, 268-269.

Rageau J.: Phébotomes du Cameroun. Bull. Soc. Path. Exot., I951, 44, 793-801.

Roubaud E. : Quelques notes sur les Phlébotomes de l'Afrique Occidentale Française. Bull. Soc, Path. Exot. I913, 6, I26-128.

$Z_{\mathrm{AHAR}}$ A. R. : Studies on Leishmaniasis vector/reservoirs and their control in the Old World. Part V, Tropical Africa. WHO/VBC 8I, 1981, 825, I-I82, unpublished document. 